\title{
MOBILE APP DEVELOPMENT FOR ACCESS TO EXTRAJUDICIAL INFORMATION OF THE JUDICIARY OF TOCANTINS
}

\author{
${ }^{*}$ Harly Carreiro Varão, ${ }^{2}$ Fernando Henrique Lima Soares, ${ }^{3}$ Marcelo Lisboa Rocha \\ and ${ }^{4}$ Gentil Veloso Barbosa
}

1, 2Developer at Tocantins Court of Justice (TJTO) and master's student at Federal University of Tocantins (UFT)

3,4 Doctor teacher at Federal University of Tocantins (UFT)

\section{ARTICLE INFO}

\section{Article History:}

Received $28^{\text {th }}$ July, 2019

Received in revised form

$19^{\text {th }}$ August, 2019

Accepted $06^{\text {th }}$ September, 2019

Published online $16^{\text {th }}$ October, 2019

\section{Key Words:}

Mobile App,Digital Seal,

Tocantins, Hybrid App Development.

*Corresponding author: Harly Carreiro Varão

\begin{abstract}
The Tocantins Court of Justice (TJTO) has achieved high levels of computerization of its cases, whether in the judicial or extrajudicial area. This scenario brings with it the need for transparency in the performance of such procedures, as well as the engagement of Tocantins citizens. The development and availability of a mobile app that enables citizens to access extrajudicial information may contribute to the consolidation of these aspects. In this sense, the objective of this research is to develop a mobile app aimed at accessing the extrajudicial information of the TJTO. For this, an exploratory research will be performed, with data collection through bibliographic research accompanied by theoretical resources, books, current legislation and electronic publications. As a result, the research will consider the time, team expertise, cost, complexity, and legislation in the context of the Tocantins Judiciary to demonstrate the advantages and disadvantages of technology factors in addressing app requirements. In the end, best practices for developing this mobile app in TJTO will be recognized, as well as its best application.
\end{abstract}

Copyright (C) 2019, Harly Carreiro Varão et al. This is an open access article distributed under the Creative Commons Attribution License, which permits unrestricted use, distribution, and reproduction in any medium, provided the original work is properly cited.

Citation: Harly Carreiro Varão, Fernando Henrique Lima Soares, Marcelo Lisboa Rocha and Gentil Veloso Barbosa, 2019. "Mobile app development for access to extrajudicial information of the Judiciary of Tocantins", International Journal of Development Research, 09, (10), 30211-30215.

\section{INTRODUCTION}

As it is considered the motivator for the elaboration of this research, the use of mobile apps has its relevance noticed with its spread as smartphones and other mobile devices become popular. According to IBGE (2017), of the 49.2 million Brazilian residential households with Internet access - which represents $69.3 \%$ of households - $97.2 \%$ do so using their mobile phones. Interesting data is also raised by FGV (2018), informing that for the first time the number of smartphones in Brazil has exceeded the number of inhabitants, that is, today the country has approximately 220 million active smart phones for a population of 210 million. In line with this reality, which seeks the need for technological alignment, the Tocantins Judiciary Branch is beginning to focus on mobile app that allow citizens to access judicial or extrajudicial information. Law No. 12,527/11 (2011), known as the Law on Access to Information (LAI), guarantees to any person requesting and receiving from public bodies, from all entities and Powers, public information produced or held by them. This made the Judiciary Power through the Judicial Ombudsman initiate negotiations for the elaboration of the project "Transparent
Judiciary". This project aims to develop and make available a multiplatform application that helps citizens to exercise their citizenship, increasingly promoting the transparency of the Tocantins Court of Justice in its actions, bringing the citizen closer to justice, as well as improving the jurisdictional provision. The referred law and the project "Transparent Judiciary" are in line with the proposal of the project "Digital Seal of Inspection and Certification of the Acts of Registrants and Notaries of the Tocantins State Extrajudicial Service" launched on March 30, 2015 (TOCANTINS, 2015). Its purpose is to verify whether an act performed in extrajudicial servant hood is authentic and valid. Thus, when the citizen goes to extrajudicial service and makes use of their services such as endorsements, powers of attorney, endorsements, etc. In the document there will be a seal code, which will enable the citizen to access the website of the Judiciary of Tocantins and verify if that printed document is true. For effective operation it is necessary that any citizen, body or institution of private or public origin, whenever practicing an act in an extrajudicial service in the state of Tocantins do the search on the site to validate the document. Given this, there are difficulties perceived by the supervisory body of extrajudicial services, which in this case is the General Court of Justice of 
the Judiciary of Tocantins. The main one is the low use of the Court's website to consult the seals used, which makes the inspection and collection process promoted by the agency difficult. Thus, this research aims to answer the following question: considering the reality of the Tocantins Judiciary, how to develop a tool that facilitates access to extrajudicial information for the citizen? Therefore, the objective of the research is to model the business rules, functional and nonfunctional requirements of this application aiming at the development and availability to the citizen of Tocantins extrajudicial services. Possible impediments to legislation and good technological practices aimed at speeding up both the development process and the use of the tool will be observed.

Considering only 2017, extrajudicial revenue exceeded R \$ 12 million with growth prospects in subsequent years (TOCANTINS, 2017). The availability of extrajudicial information on mobile devices allows citizens to confront digital seal data almost instantaneously, to verify the authenticity of the content, and to inform the General Court of Justice about possible differences between the value of the act performed and the amount paid for the service. which reflects in the collection and possible sanction with the extrajudicial service.

The concepts of software engineering, defended by Pressman and Maxim (2016) as generating artifacts that provide value to others, can be applied in the development of mobile apps, since the evolutionary aspect of this technology brought with it a need for adaptation. This is addressed by ALLEN, GRAUPERA and LUNDRIGAN (2012) in highlighting the changing utility of desktop applications and the mobile phone as the new personal computer. Milionari (2017) confirms this position by reporting that the use of mobile devices had a significant change in 2009, when data traffic outstripped voice traffic worldwide on these types of devices. This has resulted in the explosion of the use of mobile operating systems, as well as improved development for this platform. This fact can be confirmed in a study by App Annie (2017) pointing out Brazil highlighted among the countries that use different applications more per day. In this evolutionary context, Fernandes, Knop and Quintela (2017) point to the existence of two main approaches to mobile app development: native and hybrid; and recognizes that each approach has its own peculiarities and can be applied on demand. Andrade and Knop (2015), in turn, argues that to meet the variety of users, operating systems and market needs, mobile apps should prioritize multi-platform development aimed at reducing cost and time. From a technological perspective, the importance of access to extrajudicial information through mobile devices may bring great advances by contributing to the process of disclosure, supervision and collection of extrajudicial provision of the Tocantins Judiciary. In the following sections will be used knowledge of Software Engineering and a study will be done to obtain the most favorable technological scenario for the development of the application proposal object of this article.

\section{MATERIALS AND METHODS}

This work was based on the Digital Seal module (Figure 2) of the Integrated Management System for Extrajudicial Notaries (GISE) of the Tocantins State Judiciary (TJTO) and used a qualitative approach with exploratory objective, involving bibliographic research. Accompanied by theoretical resources, books and publications available electronically. According to Prodanov (2013), the exploratory research aims to obtain more information about the subject to be investigated and is characterized by its flexibility involving bibliographic survey, interviews and study of examples that stimulate understanding. Given the specific context of the research, it was characterized by its applied nature.

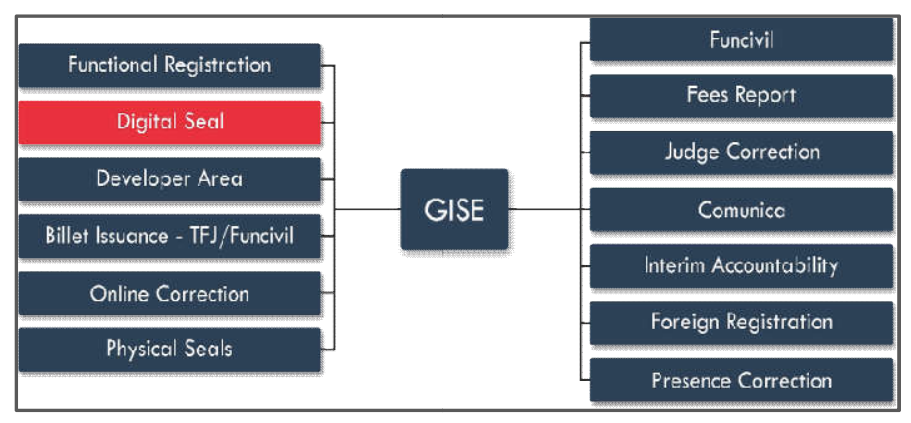

Figura 2. GISE Modules with Digital Seal highlighted (2019)

In order to gain a better understanding of the subject, a survey of part of the current literature on the subject was made, prioritizing the latest theoretical resources, which is imperative to highlight the best practices in the development of mobile apps. Literary content was obtained from searches in virtual libraries, google academic and laws in force from July 2018 to August 2019. The following parameters were used for research: conceptual modeling of mobile apps, hybrid/native app development and digital seal Tocantins. Modeling tools were used to obtain the prototyping of the screens and the Use Case diagram, as well as the app requirements survey. Although it involves communication with other systems, all modeling and development has been focused on the contents of the Digital Seal App following the established schedule that goes from the requirements gathering to its official release. There was an analysis of recent comparative studies in which it was possible to observe the existing practices to obtain the most appropriate development approach of the Digital Seal App. In this scenario, it is always important to keep in mind that the decision to choose the hybrid or native approach should be based on the organization's unique objectives, the circumstances of a given project, and the composition of the existing development team (IONIC EBOOK, 2018).

\section{Mobile App Development for Access to Extrajudicial Information}

This section aims to present the results obtained with the conceptual modeling and comparison of existing technologies for the development of mobile apps, as well as the best application of these solutions in face of the current laws governing the State of Tocantins. As it is a public body, the TJTO is governed by laws that seek to give greater transparency to the acts practiced in the context of its hiring, bidding and administrative procedures in general, which may lead to a slow process in the construction of the software. The conceptual modeling of this app proposes to balance transparency and productivity in order to extract technological concepts that comply with current legislation. The extrajudicial service execution process was also considered (Figure 3). In this process, the citizen, when performing an act in extrajudicial service, receives a code called Digital Seal, such code is sent to the system GISE (Integrated Management of Extrajudicial Services) with all data related to the act performed, which in turn provides resources for the citizen 
himself verifies the authenticity of the Digital Seal. In this process, the Court of Justice acts as the inspector of extrajudicial practice.

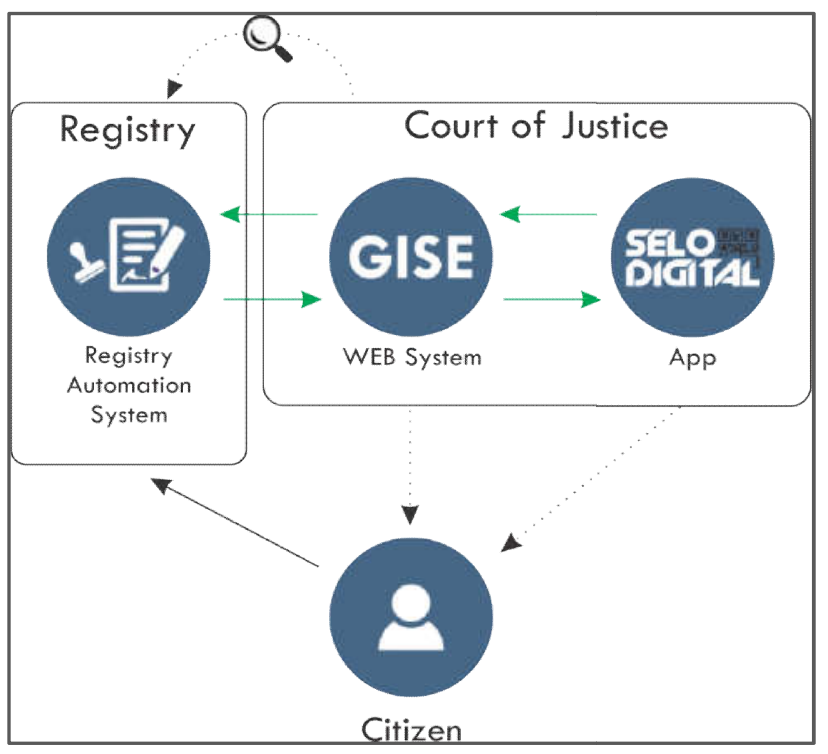

Figura 3. TJTO extrajudicial service execution process

Once in possession of the data (value, act, date, fees, taxes, CPF / CNPJ and etc.) consulted via the Digital Seal App, the citizen can confront them with the content of the act performed in extrajudicial service and verify the authenticity of the information., as well as inform the Court of Justice of possible divergences. In Figure 5, you can see the Use Case diagram of the Digital Seal App used to represent a textual narrative or model that describes a function or feature of a system from the user's point of view (PRESSMAN; MAXIM, 2016). The full description of the use case is reported in detail in Tables 1 and 2 containing the specification of the use cases and is necessary for a better understanding of what the user really wants and to highlight a more complete requirements model.

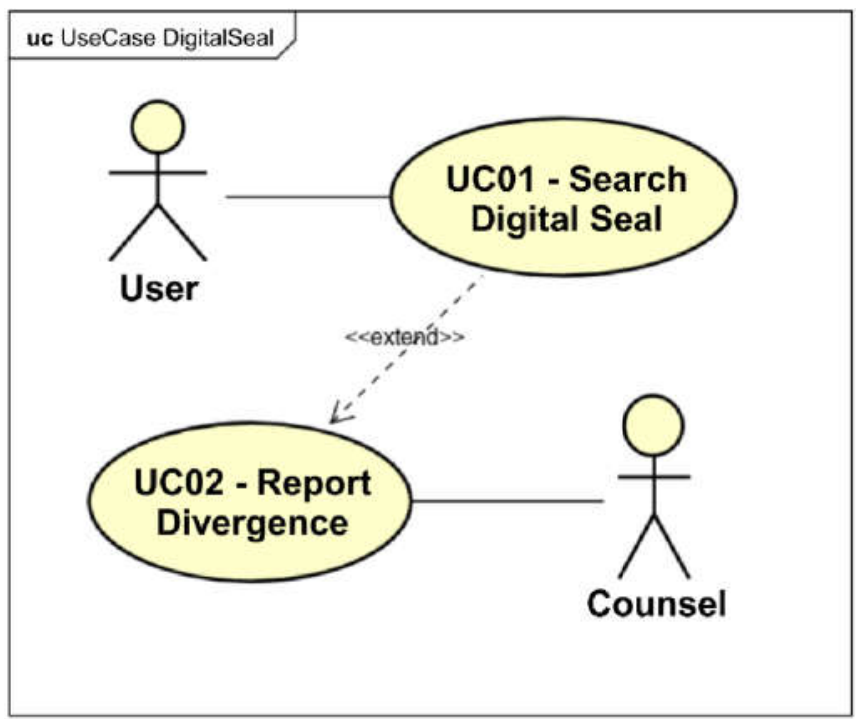

Figura 5. Digital Seal app Use Case Diagram (2019)

Software requirements are an official statement about what system developers should implement. It should include both user requirements for a system and a detailed specification of system requirements (SOMMERVILLE, 2011). As shown in Figure 6, software requirements encompass business rules and functional and non-functional requirements:
Tabela 1. Use Case Specification "UC01 - Search Digital Seal" (2019)

\begin{tabular}{|ll|}
\hline UC01 - SearchDigital Seal \\
\hline Actors & User \\
\hline Precondition & $\begin{array}{l}\text { The User must have practiced an act in } \\
\text { extrajudicial service or have access to the data } \\
\text { of an act performed. }\end{array}$ \\
\hline Mainstream & $\begin{array}{l}\text { P01: User accesses the Digital Seal App. } \\
\text { P02: The User accesses the option to search } \\
\text { Digital Seal. } \\
\text { P03: The app displays the Digital Seal search } \\
\text { screen. } \\
\text { P04: User searches for Digital Seal by entering } \\
\text { "seal" and "validation code" } \\
\text { P05: The app displays the information related to } \\
\text { the searched seal. }\end{array}$ \\
$\begin{array}{l}\text { A01 (P02): User chooses to search by QRCode. } \\
\text { - User reads QRCode from Digital Seal. } \\
\text { - The app displays the information related to } \\
\text { the searched seal. dght User reads QRCode } \\
\text { from Digital Seal. }\end{array}$ \\
\hline $\begin{array}{l}\text { E01 (P06): The seal and validation code fields } \\
\text { are required. } \\
\text { E02 (P06). Seal does not exist or no information } \\
\text { was given to the TJTO about this seal. }\end{array}$ \\
\begin{tabular}{l} 
None \\
\hline Postconditions
\end{tabular} \\
\hline
\end{tabular}

Tabela 2. Use Case Specification "UC02 - Report Divergence" (2019)

\begin{tabular}{|ll|}
\hline UC02 - Informar Divergência \\
\hline Actors & User, Courtof Justice \\
\hline Precondition & The User has searched the seal (UC01 - Search \\
& $\begin{array}{l}\text { Digital Seal) by the Digital Seal App. } \\
\text { The User has noticed any divergence in the data } \\
\text { of the act performed. }\end{array}$ \\
\hline Mainstream & $\begin{array}{l}\text { P01: User uses "Click here" option on Digital } \\
\text { Seal search result screen. } \\
\text { P02: The User enters a contact email. } \\
\text { P03: User describes perceived divergence. } \\
\text { P04: User submits divergence. } \\
\text { P05: The app displays the divergence number } \\
\text { generated by the app and the contact deadline. } \\
\text { P06: Court of Justice contacts the User via } \\
\text { email. }\end{array}$ \\
\hline Alternativestreams & None \\
\hline Exceptions & $\begin{array}{l}\text { E01 (P05): The fields "email" and "description" } \\
\text { are required. }\end{array}$ \\
\hline Postconditions & $\begin{array}{l}\text { The divergence is informed to the Court of } \\
\text { Justice. }\end{array}$ \\
\hline
\end{tabular}

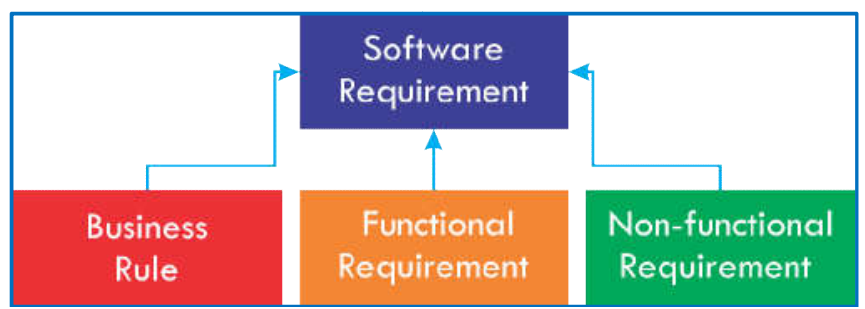

Figura 6. Software Requirement Graphing

The Digital Seal App business rules are based on the premise that extra-judicial service needs to be made more transparent and accessible to citizens. A possible consequence could be a higher extrajudicial collection, as well as a better supervision of extrajudicial services and a reduction of possible infractions during extrajudicial service. Thus were listed the business rules: the citizen must have access to the digital seal of the act performed in an extrajudicial service (BR01), the citizen can verify the authenticity of the act performed (BR02); The citizen may report possible disagreements to the Court of Justice (BR03); the Court of Justice should contact the citizen to clarify the perceived divergence (BR04). Functional 
requirements are statements of services that the system must provide, how the system should react to specific inputs, and how the system should behave in certain situations while nonfunctional requirements are restrictions on services or functions offered by the system (SOMMERVILLE, 2011). Digital Seal App Functional Requirements: Enable Digital Seal searching via mobile app (FR01); list the act data related to the searched Digital Seal (FR02); allow information to the Court of Justice of possible divergences (FR03). Nonfunctional Digital Seal App Requirements: The software must be a mobile app (NFR01); the app should allow access by the most widespread mobile operating systems (NFR02); the app must allow access without the need for installation (NFR03); There will be communication with the Integrated Management System of Extrajudicial Services (GISE) via web service to obtain the data and inform the possible divergences (NFR04); the time available to consult the act may be up to 30 minutes (NFR05); the time for analysis of the possible divergence by Court of Justice may not exceed three business days (NFR06); the system will use the Ionic framework for multiplatform implementation (RNF07); The app will be developed using the Type Script language (NFR08); GitHub platform for version control (NFR09) will be used; The Cordova library will be used for integration with native mobile device features (NFR10). With the software requirements defined, one of the most important factors in mobile app development must be brought to light for the effective achievement of what has been defined in business rules, functional and non-functional requirements: the development approach. In choosing the most appropriate form of mobile app development, factors such as time, cost, expertise, market, and complexity should be considered. Thus, it should be considered that the Tocantins Court of Justice has three web developers working in the extrajudicial area, being responsible for all state demand. In this context, also considering the study of Table 3, the hybrid approach is better suited to the development of the Selo Digital App, since existing knowledge in HTML, Javascript and CSS can be used to mitigate costs, delivery time, complexity of the project.

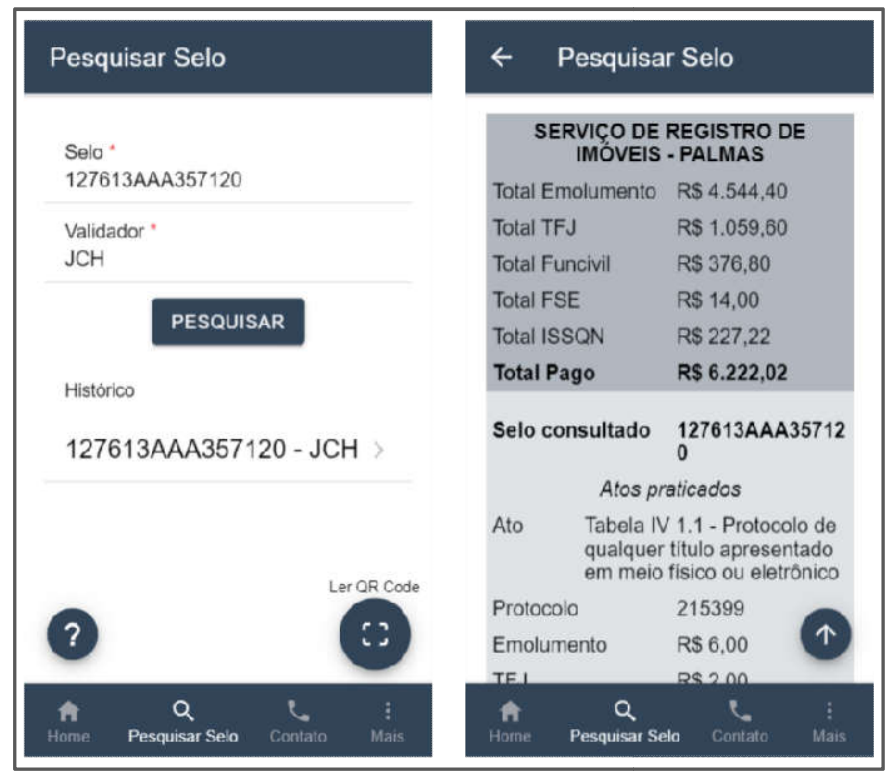

Figura 9. Seal search screens in the Digital Seal App (2019)

In addition, the Digital Seal app (Figure 9) should reach as many citizens as possible as it is an advertising tool for extrajudicial acts. The hybrid approach has several forms of app distribution, generating significant coverage. One form of distribution is achieved through Progressive Web App (PWA) technology, in which the user enjoys a mobile app through a full-screen browser that enables native functionality without downloading apps in virtual stores. PWA can be very useful to avoid possible lengthy bidding processes for publishing content in online stores.

\section{Conclusion}

The Tocantins Court of Justice has most of its work converted to digital reality, which has led to extrajudicial jurisdictional provision at the same level in the services offered. Access to extrajudicial information enables greater transparency and engagement on the part of citizens by contributing to the process of oversight of extrajudicial services. The Digital Seal App is characterized as an aid tool in the extrajudicial jurisdictional provision and its construction needs to be guided by the reality observed in the Tocantins Judiciary. Based on the bibliographic review used in the research on the theme, it was possible to identify the aspects to be considered in the development of the app and which would best fit the needs of the agency. It was concluded that the hybrid approach best fits the objectives of the Digital Seal App regarding its development, since it deals with the whole process balancing the variables: time, cost, team expertise, complexity and market (legislation and context). Tocantins Judiciary). The documentation obtained also brought to light the user's needs in view of the extrajudicial jurisdictional provision, highlighting the app's contribution to the transparency and effectiveness of the registry proceedings in the light of current legislation. Finally, it is understood that the content used brings the latest technology to build the Digital Seal App aiming its conceptual modeling, establishing precepts based on the pillars that govern public management in the Tocantins and offering the larger citizen possibility of being a protagonist in relation to the good applicability of the taxes collected before the extrajudicial judicial provision of the Tocantins Judiciary.

\section{Acknowledgments}

The authors are great fully acknowledged to the team of the Information Technology Department of the Tocantins Court of Justice (DTINF)for providing the necessary data for this research, as well as for their collaboration during the development of the mobile app. Authors are also thankful to the management of the Tocantins Court of Justice (TJTO) for the institutional and financial support for this project.

\section{REFERENCES}

ALLEN, Sarah; GRAUPERA, Vidal; LUNDRIGAN, Lee. Desenvolvimentoprofissional multiplataforma para smartphone: iPhone, Android, Windows mobile eBlack Berry. Rio de Janeiro: Alta Books, 2012. xvi, 264 p. ISBN 9788576086611.

ANDRADE, Marlon M.; KNOP, Igor O., Projeto e desenvolvimento de jogos eletrônicos multiplataforma: um estudo de caso utilizando Cocos2d-x,p. 1, 2015. ISSN: 2446-6204. Disponível em: < https://seer.cesjf.br/index. php/cesi/article/view/300/396 >. Acessoem 18/02/2019.

APP ANNIE. Discover the Countries Leading in App Usage, 2017. Disponível em: <https://www.appannie.com/ en/insights/market-data/global-consumer-app-usage-data/> Acesso em 12/02/2019. 
BRASIL. Lei $\mathrm{n}^{\mathrm{o}} 12.527,18$ de novembro de 2011. Regula o acesso a informaçõesprevisto no inciso XXXIII do art. 5o, no inciso II do $\S 30$ do art. 37 e no $\S 20$ do art.216 da Constituição Federal; altera a Lei no 8.112, de 11 de dezembro de 1990; revogaa Lei no 11.111 , de 5 de maio de 2005, e dispositivos da Lei no 8.159 , de 8 de janeirode 1991; e dá outras providências. Disponível em: $<$ http://www.planalto.gov.br/ccivil_03/_ato20112014/2011/lei/112527.htm>. Acesso em²5/07/2018.

BRASIL. IBGE. Características gerais dos domicílios e dos moradores 2017. PNADContínua, 2017. Disponível em: $<$ https://agenciadenoticias.ibge.gov.br/media/com_med iaibge/arquivos/983c56b6748df13690bcab63b5f631c1.pdf $>$ Acesso em 25/07/2018

CORRAL, L., JANES, A., REMENCIUS, T. Potential Advantages and Disadvantages of Multiplatform Development Frameworks - A Vision on Mobile Environments. Procedia Computer Science, v. 10, p. 1203, jan. 2012. ISSN 1877-0509. Disponível em:<http://www. sciencedirect.com/science/article/pii/S1877050912005303 >. Acesso em 20/02/2019.

FERNANDES, Gabriel do N.; KNOP, Igor O.; QUINTELA, Bárbara M..Projeto e desenvolvimento de aplicações para dispositivos móveis híbridas a partir de tecnologias para Web: um estudo de caso em jogos digitais, 2017, p. 3, Disponível em: <https://seer.cesjf.br/ index.php/cesi/ article/view/1263/922>.Acessoem15/02/2019.

IONIC EBOOK, Hybrid vs. Native. Na introduction to crossplatform hybrid development for architects and app development leaders. Disponível em: <https:/eaesp.fgv. br/sites/eaesp.fgv.br/files/pesti2018gvciappt.pdf> Acesso em25/07/2018.

MEIRELLES, S. Fernando. 29a Pesquisa Anual do Uso de TI. São Paulo: FGV-SP,2018. Disponível em: < https://eaesp.fgv.br/sites/eaesp.fgv.br/files/pesti2018gvciap pt.pdf $>$ Acesso em25/07/2018.

MILIONARI, Leonardo. Testes de aplicações mobile: qualidade e desenvolvimento em aplicativos móveis. São José dos Campos, SP: Érica, 2017.

TOCANTINS. Judiciário Transparente, Processo Administrativo $\mathrm{n}^{\circ} 17.0 .000027053-9$. Disponível em: < https://sei.tjto.jus.br> Acesso em 25/07/2018.

TOCANTINS. Relatório de Atividades. 2017. Disponível em: $<$ http://wwa.tjto.jus.br/transmetas/Uploads/transparencia_r elatorio_anual_cgjus/RelatorioAnual2017.pdf $>$ Acesso em 19/04/2019.

TOCANTINS. Selo Digital: transparência, agilidade e segurança para o usuário. 2015. Disponível em: < http://www.tjto.jus.br/index.php/noticias/3307-selo-digitaltransparencia-agilidade-e-seguranca-para-o-usuario Acesso em 19/02/2019.

PRESSMAN, Roger S.; MAXIM, Bruce R.,Engenharia de software: uma abordagem profissional / Roger S. Pressman, Bruce R. Maxim; tradução Ariovaldo Griesi; revisão técnica: Reginaldo Arakaki, Julio Arakaki, Renato Manzan de Andrade. - 8. ed. - Porto Alegre: AMGH, p. 45-165, 2016.

PRODANOV, Cleber Cristiano. Metodologia do trabalho científico [recurso eletrônico] : métodos e técnicas da pesquisa e do trabalho acadêmico / Cleber Cristiano Prodanov, Ernani Cesar de Freitas. - 2. ed. - Novo Hamburgo: Feevale, p, 52, 2013.

SOMMERVILLE, Ian. Engenharia de Software / Ian Sommerville; traducao Ivan Bosnic e Kalinka G. de O. Goncalves; revisaotecnicaKechiHirama. - 9. ed. - Sao Paulo: Pearson Prentice Hall, p. 3- 91, 2011. 